\title{
THE FINANCIAL BEHAVIOR OF HOUSEHOLDS IN UKRAINE
}

\section{- Lyudmyla Shkvarchuk, Rostyslav Slav'yuk}

\begin{abstract}
The purpose of this paper is to evaluate the peculiarities of the financial behavior of households as one of the main factors of country competitiveness. The authors undertook to fulfill this aim by dividing household expenditures into fixed and variable elements, and investigating each element separately. The analysis is based on data from the State Statistics Service of Ukraine and encompasses the period of 2001-2017. A chi-square test was used to test the selected data. A high propensity of households to consume stimulates a greater internal market size within a country, a correlation which is also an important indicator of competitiveness in Ukraine, where a high proportion of savings of household income is typical. The situation in Ukraine shows a great positive impact of savings to the development of the local financial market. Ukrainian households tend to accumulate savings with the intent of creating a financial safety net for themselves in anticipation of future economic downturns. As is the case in many Central and Eastern European countries, Ukrainian households hold most of their savings in foreign currency and bank deposits. This allocation has proven itself to be resilient to changes in the expected returns of the assets in question. The marginal propensity of Ukrainian households to purchase non-financial assets is small, but relatively stable. The internal crisis in 2014-2016 triggered substantial changes in the financial behavior of Ukrainian households. The post crisis period of 2017 has not yet significantly changed the financial behavior of Ukrainian households. As in the past, today households keep a great deal of cash outside the banking system, with the largest share of the non-financial assets of households held in foreign currency.
\end{abstract}

Keywords: country competitiveness, financial behavior, household saving, household financial choice, financial assets

JEL Classification: D14, G 40

Received: March, 2019

1st Revision: June, 2019

Accepted: July, 2019

\section{INTRODUCTION}

Competitiveness has been generally defined as a set of factors that determine the level of productivity within a country, taking into account its level of development. Market size is one such factor which can paint a picture of a country's ability to attract investments, raise per capita GDP, as well as create jobs and wealth for people. Domestic market size depends on consumer behavior, 
thus there is a close direct link between the volume of household consumption and the level of competitiveness of a country. Indeed, an economy's ability to develop its growth prospects along with a degree of resistance to exogenous shocks depends on the behavior of consumers and their expectations regarding retail market trends.

Each stage of a society's development is defined by certain distinct features and characteristics, the vast majority of which depict Ukraine as a consumer society with individual consumption being prevalent. According to the World Economic Forum's Global Competitiveness Report, domestic market size has been one of the main drivers of economic growth of Ukraine in the last 16 years.

A society's propensity to save is one aspect which can define its investment potential. In aggregate, the households of many countries own vast amounts of financial assets, which are an important internal resource to be utilized in financing economic development. The transformation of savings into investments is a complex process influenced by a broad array of both objective and subjective factors.

To be effective, the government's social and economic policies should aim to facilitate the process of transforming savings into investments, a goal which will present the opportunity to increase the competitiveness of the country. National governments usually offer numerous savings and investment tax schemes to encourage the residents of their countries to save and invest more. In order for the government to maximize the effectiveness of such policies, it is crucial for it to understand the particularities of the financial behavior of individuals under the prevailing social and economic conditions, as well as to be able to forecast and manage such behavior.

The need to investigate the particularities of behavioral economics within the context of a particular territory is increasingly coming to the forefront of financial research. For example, Illyashenko (2017) emphasizes the possibility of using behavioral finance as a means of determining the effectiveness of political decisions within various spheres. Given that individual actors in financial markets tend to react to ambiguous situations differently depending on how the circumstances are presented, the ability to adequately evaluate patterns of financial behavior is crucial for developing methods of effectively charting the development trajectory of individual segments of the financial market as well as of the economy as a whole.

The main aim of this article is to determine the most significant features of the financial behavior of Ukrainian households before and during the financial crises. We would like to test the hypothesis that maintaining savings is the variable element in the allocation of income, i.e. one which forms a choice set which can define the financial behavior of households. The study evaluates the influence of external and internal factors on the financial behavior of households. Out of the large number of external factors that influence the financial decision-making process, we single out two: income level and market conditions. Among the internal factors, we devote particular attention to the influence that the psychological particularities of Ukrainian households have on their financial decisions.

\section{THEORETICAL BACKGROUND}

One relatively recent development of economic science is an intensification of research in behavioral finance, a field which the Academy of Behavioral Finance \& Economics describes as quite promising. Significant contributions to developing a theoretical and practical basis for identify- 
ing the factors, schemes and models of the behavior of individuals within financial markets have been made by scientists representing different fields in the economic, psychological and social sciences. Thaler, the 2017 Nobel Prize winner in Economics, describes the study of behavioral finance as unbiased and progressive (Thaler, 1993), thus demonstrating the actuality of the chosen research directions and methods.

The study of household finance is challenging, as household behavior is difficult to measure. Yamana (2016) asserts that the analysis of household finance has non-negligible implications in asset pricing literature as well as in other areas, but empirical research on this topic is a challenging task.

Research in the field of household finance is developing in several directions on both the macroeconomic and the microeconomic level. On the microeconomic level, it encompasses the evaluation of the economic and financial conditions of personal portfolio choice decisions. Campbell (2006) points out that there are two key challenges when it comes to household finance: how to measure household portfolio choice precisely, and how decision-making is to be adequately modeled. Yamana (2016) adds to this list the issue of how to estimate structural parameters in the proposed theoretical model using the data of household portfolio choice. In their work the researchers focus primarily on measuring the correlation between the household activity in the financial market and the prices of various assets, particularly shares. These theoretical challenges have been dealt with using what have been called consumption-based asset pricing models (C-CAPM; Ludvigson, 2015).

In recent decades, research on changes in the financial behavior of households has become popular due to changes in the macroeconomic situation. For example, Kolasa \& Liberda (2015) verify the statistical relationships between the amount of savings of Polish households and other attributes such as income, family demographics, and the size of the place of residence. Utzig (2016) identifies and evaluates changes in the value and structure of household financial assets in Poland in the years 2003-2014, also taking into consideration changes in the economic environment. Hronová \& Hindls (2013) compare the behavior of Czech households in the late 90s to that of the period 2009 - 2012, re-counting the response of households to the 2008 economic crisis. Zhuk (2015) has investigated the most significant macroeconomic indicators that influence the accumulation of household savings in Ukraine.

The financial affairs of individual households invariably have an strong impact on a country's economy. Hence, from a macroeconomic perspective there is a need to investigate the specificity of the influences that households have on the dynamics of financial markets, as well as on the overall financial system with particular countries. Côté (2011) has also described how household finances have important implications for financial stability, i.e. while the rapid expansion of household credit during a recession and early stages of a recovery period is in part a testament to the resilience of a financial system, it is also a source of risk.

Most of this research focuses on the problems of interactions among the behavior of households and the prevailing credit market conditions, along with the prices of particular assets. This focus can be traced back to the intensification of such research in the wake of the 2008 financial crisis, the causes and effects of which were closely tied to the actions of households on the credit 
market. For example, Stango \& Zinman (2007) generated distinct behavioral predictions regarding the relationships between biased perceptions and portfolio choice, wealth levels, and the use and benefits of financial advice. Further developing their theory, Stango \& Zinman (2009) demonstrated that more-biased households borrow more, save less, favor shorter maturities, as well as use and benefit more from financial advice, a set of behaviors conditional on a rich set of household characteristics. Choi et al. (2009) have shown that individual investors over-extrapolate from their personal experience when making savings decisions.

Modern scientists devote less attention to researching the influence of household behavior on general economic development. The impact of capitalist change on households is also of central concern in the International Political Economy literature of "daily life." But, as Fuller (2015) points out, even within IPE communities that do focus on households, there remains a tendency to understate the importance of household finance. While mainstream macroeconomics does have a track record of viewing households as key shapers of economic equilibrium, the field is limited in other ways. As it is not especially sophisticated in its incorporation of institutions - and because the field assumes a large degree of causal universalism - macroeconomics is generally blind to how markets evolve over time and diverge across space. Given that households are a key ingredient in determining the volume and direction of global financial flows, it stands to reason that modern economic science should focus more closely on the actions of households and the fundamental causes of said actions.

It is worth mentioning that during the past couple of years, there have also been some attempts to create overarching models (similar to the ones in mainstream macroeconomics) that treat household finance as a key variable in determining the overall economic activity. The research of Froud et al. (2010) has proven that, taken to the extreme, such a democratization of finance might allow households to escape "the tyranny of earned income" as their returns as for rentiers become more important than their wages as for workers.

The characteristic feature of the approach taken by these researchers is the re-orientation of the methodology from the evaluating a rational economic agent's behavior, which is ubiquitous in classical economics, to analyzing the behavior of "ordinary (real) individuals", who are susceptible to making systematical and predictable errors and taking irrational financial decisions. In particular, the evidence of participation, diversification, and mortgage refinancing suggests that many households invest effectively, but a minority of them do make significant mistakes.

Based on the described approach, we aim to evaluate the main characteristics of the financial behavior of Ukrainians.

\section{RESEARCH OBJECTIVE, METHODOLOGY AND DATA}

Our research is based on the principle of methodological individualism, allowing us to explain social phenomena with the actions of individuals, as well as on the approaches of Barber \& Odean (2001), which we enhanced by evaluating approximated indicators of people's financial behavior, given that we are interested in the consequences of financial decisions for forecasting the indicators that characterize certain segments of financial markets from both the quantitative and qualitative perspective, rather than in the criteria that drive each separate individual's financial decisions as such. 
One of the most famous investigations of the particularities of consumption and investment was carried out by the Nobel Prize winner Stone (1966).We follow his methodology to evaluate the character of the financial behavior of Ukrainian households.

Unlike Stone's approach, who researched the constant and variable elements of income, we will evaluate the households' allocation of income by dividing it into the following elements: 1) current consumption expenses (CC); 2) expenditures on purchasing assets (growth in non-financial assets ownership or wealth) (W); 3) savings (growth in financial assets ownership) (S). The described allocation consists of both fixed and variable elements. Current consumption expenses include all the expenses necessary to finance a household's daily needs and are, therefore, assumed to be fixed. The variable element includes expenditures on buying durable household goods (non-financial assets), and savings (buying financial assets). Mathematically, we can express this as follows:

$$
\begin{aligned}
& \Delta I=\alpha \times(\Delta C C+\Delta W)+\beta \times \Delta S, \\
& I=C C+W+S,
\end{aligned}
$$

Where $\Delta \mathrm{I}$ is the change in current period income; $\Delta \mathrm{CC}, \Delta \mathrm{S}, \Delta \mathrm{W}$ are the changes in current consumption, financial and non-financial assets, respectively; $\alpha$, $\beta$ are the marginal propensities to consume and to save, respectively, with $\alpha+\beta=1$.

Given that consumer expenses $(C)$ are the sum of current consumption expenses (CC) and wealth accumulation (W), the increase in incurrent consumption expenses $(\Delta C C)$ can be calculated using marginal indicators:

$\Delta C C=\Delta I \times \alpha-\Delta I \times \mu=\Delta I \times(\alpha-\mu)$

Where $\mu$ is the marginal propensity to accumulate non-financial assets.

Substituting equation (3) into equation (1) we get:

$\Delta I=\alpha \times(\Delta I \times(\alpha-\mu)+\Delta W)+\beta \times \Delta S$,

After transforming equation (4), we arrive at the following relationship:

$\Delta S / \Delta I \times \beta=\alpha \times(\alpha-\mu)-1+\Delta W / \Delta I \times \alpha$

The expression $\Delta \mathrm{S} / \Delta \mathrm{I} \times \beta$ represents the change in household savings $(\Delta \mathrm{S})$ in the current period that is being caused by the change in income $(\Delta \mathrm{I})$, taking into account the marginal propensity of households to save $(\beta)$. The expression $\Delta \mathrm{W} / \Delta \mathrm{I} \times \alpha$ represents the change in household expenditures on non-financial assets in the current period that is being caused by the change in income $(\Delta \mathrm{I})$, taking into account the marginal propensity of households to consume $(\alpha)$. The fact that these two expressions are written on either side of equation (5) shows that financial and non-financial assets are substitutes for each other.

Equation (5) confirms the validity of our assumption that current consumption expenses (CC) are the fixed element in the allocation of income, and expenses on non-financial assets (W) and savings (S) are the variable elements that form a choice set defining the financial behavior of households. 
We evaluate the peculiarities of the financial behavior of households using statistical data from The Annual Reports published on the official websites of the State Statistics Service of Ukraine and The Organisation for Economic Co-operation and Development (OECD).

\section{RESULTS AND DISCUSSION}

\subsection{Households' propensities to consume and to save}

Ukraine is one of the poorest countries in Europe in terms of per capita income, yet its savingsto-income ratio exceeds the European average and is one of the highest among Eastern European countries. This gives substantial grounds to assert that the behavior of Ukrainian households indeed does have its peculiarities. Furthermore, this behavior largely determines the level of competitiveness of the country. The calculations showed that there is no direct link between the level of the households' disposable income and the score of the Global Competitiveness Index of Ukraine $(\sigma 1=-0,03)$. However, there is a thick link between the level of the households' disposable income and the size of the market $(\sigma 2=0.54)$. As the market size is one of the factors of a country's competitiveness, we can state that there is a misleading link between the consumer and financial behavior of households and the competitiveness of the country.

According to statistical data, in 2016 and 2017, personal savings in Ukraine were negative and, at -9262 million UAH, stood at their lowest level since the 1990s. Nevertheless, generally speaking, the propensity of Ukrainian households to save is high, as shown in Table 1. Having said that, it is difficult to accurately interpret absolute indicators, and practically impossible to make meaningful comparisons based on them. Because our aim is to uncover the particularities of the financial behavior of Ukrainians, it is necessary for us to compare indicators vertically between different countries. This is best achieved by using relative, rather than absolute, indicators.

Tab. 1. - Household savings by countries, $\%$ of household disposable income*

\begin{tabular}{|c|c|c|c|c|c|c|c|c|c|c|c|c|c|c|}
\hline & 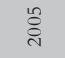 & ஜั & ڤิ & $\stackrel{\infty}{\stackrel{్}{్}}$ & ڤે & 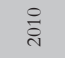 & $\overline{\bar{\Xi}}$ & $\stackrel{\sim}{\stackrel{\sim}{\sim}}$ & 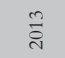 & $\stackrel{\vec{N}}{\vec{N}}$ & 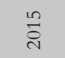 & 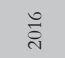 & $\hat{\stackrel{\sim}{~}}$ & 迎 \\
\hline Poland & 2.17 & 2.03 & 2.05 & 0.30 & 2.82 & 2.38 & -1.09 & -1.11 & -0.07 & -0.36 & -0.44 & 1.67 & $\ldots$ & 0.85 \\
\hline $\begin{array}{l}\text { Slovak } \\
\text { Republic }\end{array}$ & 1.10 & 0.13 & 1.90 & 0.78 & 2.33 & 2.36 & 0.76 & 0.74 & 0.21 & 1.45 & 3.03 & 2.96 & 2.41 & 1.55 \\
\hline Hungary & 7.99 & 8.56 & 4.37 & 3.66 & 5.55 & 6.11 & 6.99 & 5.24 & 7.10 & 8.04 & 6.21 & 8.05 & 7.35 & 6.55 \\
\hline Latvia & -6.53 & -11.51 & -10.75 & 3.27 & 6.31 & -1.26 & -15.91 & -14.97 & -15.27 & -12.67 & -8.11 & -3.99 & -5.80 & -7.47 \\
\hline Estonia & -8.57 & -10.89 & -6.91 & 1.86 & 7.19 & 4.17 & 4.82 & 5.06 & 4.39 & 6.45 & 6.79 & 6.51 & 7.88 & 2.21 \\
\hline $\begin{array}{l}\text { Euro- } \\
\text { pean } \\
\text { Union }\end{array}$ & 5.56 & 5.09 & 4.90 & 5.17 & 7.03 & 6.09 & 5.21 & 4.91 & 4.97 & 4.85 & 4.82 & 4.64 & 3.43 & 5.13 \\
\hline $\begin{array}{l}\text { Ukraine } \\
* *\end{array}$ & 11.58 & 8.45 & 6.59 & 2.89 & 8.45 & 13.83 & 10.51 & 11.04 & 7.69 & 2.03 & 0.95 & -0.51 & -1.20 & 6.33 \\
\hline
\end{tabular}

Source: *OECD (2017), Household financial assets (indicator). **Authors' results.

First of all, we want to prove the correctness of the application of the Stone approach to the conditions of Ukraine. The validity of the hypothesis will be checked with the help of chi-square test (see Table 2). The hypothesis H1: the households' allocation of income is evenly distributed. 
Tab. 2 - Pilot parameters of chi-square test hypothesis H1. Source: own research

\begin{tabular}{|l|l|l|}
\hline Category & Observed & Expected \\
\hline$\Delta C C$ & 4 & 2.00 \\
\hline$\Delta C C+\Delta \mathrm{W}$ & 5 & 4.00 \\
\hline$\Delta C C+\Delta S$ & 1 & 4.00 \\
\hline$\Delta C C+\Delta \mathrm{W}+\Delta \mathrm{S}$ & 6 & 6.00 \\
\hline
\end{tabular}

The empirical value of $\chi^{2}$ test statistic is 0.212 , while the critical value of $\chi^{2}$ test statistic for significance level at the 0.05 level and $\mathrm{df}=3$ is 7.814. As the critical value is higher than empirical value the hypothesis $\mathrm{H} 1$ should be rejected: the households' allocation of income is not evenly distributed. So, our primary assumption that current consumption expenses (CC) are the fixed element allocation of income and others ( $\mathrm{S}$ and $\mathrm{W}$ ) are the variable elements is correct.

The calculated average Marginal Propensity to Save ( $\beta$ ) (MPS) of Ukrainian households between 2001 and 2016 was negative and stood at -0.13 . This means that during the analyzed period, increases in household expenses were financed not only by increases in income, but also by borrowing and using the savings accumulated in the previous periods. It is worth mentioning that a low MPS is typical for most Eastern European countries, which are similar to Ukraine in terms of size and stage of economic development. For example, according to the data of the National Bank of Slovakia (Vladová, 2005), the Marginal Propensity to Save of Slovak households between 2000 and 2004 stood at 0.07 . The MPS is typically low during periods of a rapid economic decline or growth. In the first case, this can be explained by the decrease in household income and the resultant necessity to use the savings accumulated by them during previous periods to maintain their living standards. Under such circumstances, a low MPS is an inevitable consequence of the negative influence of the external environment.

During the periods of economic expansion, both incomes and the borrowing power of households increase. Having said that, it should also be noted that society's wealth is defined not by the absolute amounts of cash inflows but by the purchasing power of the inflows mentioned. Hence, during the periods of robust economic growth, households use borrowed financial resources to buy real estate, vehicles, durable goods and other similar products. This increase in borrowing puts downwards pressure on the MPS, explaining the net negative savings of Polish and Latvian households over the past couple of years (see Tab. 1).

The low MPS of Ukrainian households could have been caused either by a lack of ability to save, or a lack of willingness to save. To determine the reasons behind this behavior of Ukrainian households, we calculated their marginal propensity to accumulate non-financial assets $(\mu)$, keeping in mind that purchasing non-financial assets is a close substitute to saving. Over the analyzed period $\mu$, on average, stood at -0.01 , which is less than $\beta$ (see Tab. 3). The situation of $\beta$ being higher than $\mu$ points to a high volatility of the MPS $(\beta)$ in Ukraine, and a relatively low volatility of the marginal propensity to accumulate non-financial assets $(\mu)$. 
Tab. 3 - Marginal indicators of the allocation of household income in Ukraine in 2002-2017. Source: own research

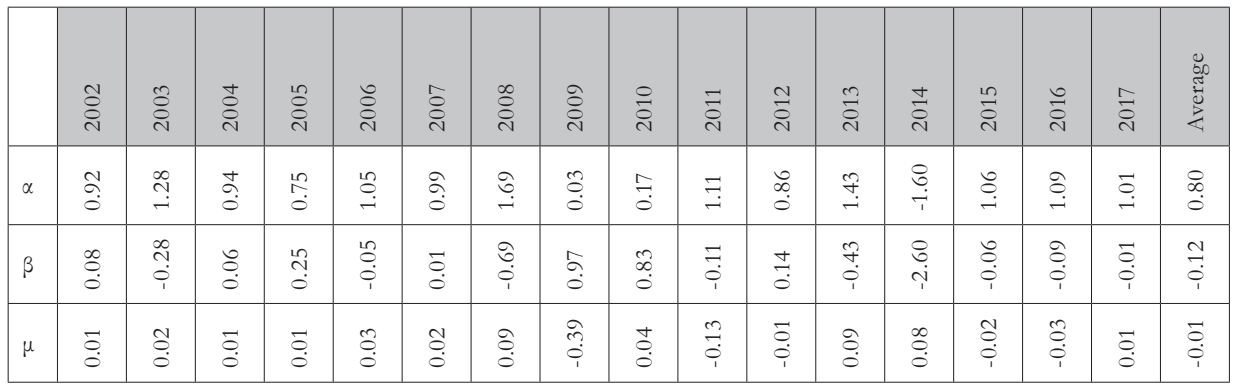

An analysis of the official statistical data regarding the allocation of income between the elements of variable expenses ( $\mathrm{SvsW}$ ) shows that in 56.25\% (9/16) of cases. Ukrainian households made the decision to buy financial assets. and in $43.75 \%$ (7/16) of cases - to buy non-financial assets. This shows that Ukrainian households find both alternatives quite attractive and that neither of them can be considered dominant. However. the average absolute amount of financial resources directed by households towards purchasing financial assets exceeds the amount invested in non-financial assets at least several-fold (see Fig. 1).

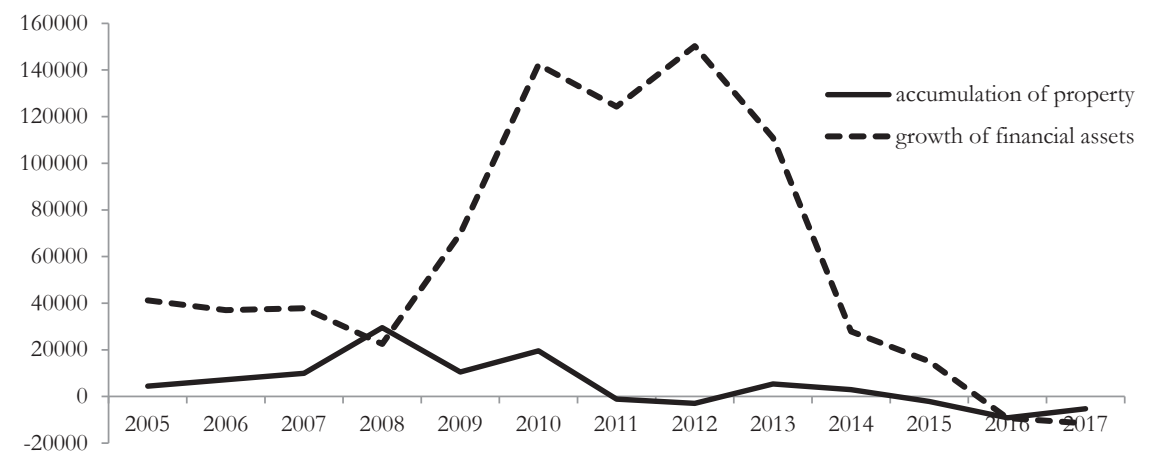

Fig. 1 - Dynamics of the variable elements of housebold expenditures in 2001-2017. Source: own research

In the classical economic theory. the default assumption is that asset allocation decisions of households are driven by expectations regarding returns and liquidity. We evaluate the extent to which this holds true for Ukrainian households by using the correlation analysis.

The State Statistics Agency of Ukraine provides aggregate information about the amount of income Ukrainian households receive from owning both financial and non-financial assets. This makes it impossible to evaluate the rationality of their allocation decisions from the point of view of the expected return on each asset class taken separately. Therefore. we evaluated pairwise interactions of each type of variable expenses with the income received from owning both financial and non-financial assets. 
The calculated Pearson correlation coefficients ( $r$ ) allow us to conclude that expected returns are not the determining factor for households when it comes to decision regarding purchasing financial assets: $\mathrm{rS}=0.2894$ indicates there is a weak positive linear relationship between the variables. Thus, the prospect of earning additional income is not the key motive underlying households' asset allocation decisions. making such decisions suboptimal from a financial perspective. The two main reasons explaining this behavior are as follows:

1. the inadequate financial competence of households caused by a low level of society's financial literacy;

2. a lack of attractive alternative forms of savings with equivalent accessibility and convenience characteristics.

The proportion of the income of Ukrainian households that is directed towards purchasing financial assets is highly variable. It reached its peak level of 150.23 billion UAH in 2012, amounting to $10.31 \%$ of income. During this period, the savings-to-income ratio of Ukrainian households was the highest in Eastern Europe and among the highest in the world. Of all the other countries, only Chile had a comparable ratio $(10.27 \%$ of the income available), and three countries had higher ratios: Sweden (15.34\%). Switzerland (18.52\%). and China (38.11\%).

The calculated Pearson correlation coefficient between the income level of households and the amount of their investments in non-financial assets stands at $\mathrm{rW}=-0.4832$, affirming the existence of an insignificant inverse relationship between the variables.

Hence, we can conclude that households accumulate non-financial assets to satisfy their individual needs rather than with the aim of receiving financial benefits from their ownership. In other words, such expenses do not meet the economic definition of an investment, and we are therefore correct in categorizing them as household consumer spending.

Motor vehicles and personal real estate are the most widespread types of durable assets owned by households. Among European countries. Ukrainian households have the lowest ownership ratios of the assets mentioned. According to statistical data, at only 22.96 square meters, the per capita size of Ukraine's dwelling stock is one of the lowest in Europe. According to Eurostat, among the EU countries, the dwelling stock in 2009 was the lowest in Romania $(15.0 \mathrm{~m} 2$ /person). Lithuania (24.9 $\mathrm{m} 2$ /person), and Slovakia (26.0 $\mathrm{m} 2$ /person).

According to the data gathered by AUTO-Consulting, at 202 cars per 1.000 inhabitants, in 2016. Ukraine had the lowest motorization rate (i.e. the amount of passenger cars per 1.000 inhabitants) in Europe. Amongst the EU Member States with the highest motorization rates, there are several smaller countries. Luxembourg (661 passenger cars per 1.000 inhabitants) heads the list. Other countries with a high motorization rate include Italy (610 cars: 2014 data). Finland (590 cars) and Cyprus (575 cars). At the other end of the scale, a particularly low motorization rate is recorded in Romania (261 cars), despite a growth in the number of registered cars of almost 19\% over the last five years. However, the motorization rate is still substantially lower in the candidate countries than in the EU Member States, with a motorization rate of 134 cars per 1.000 inhabitants (Turkey). Thus, the urge of Ukrainian households to accumulate non-financial assets stems primarily from the exceedingly low per capita stock levels of the said assets in the country. 


\subsection{Variable elements allocation of households' income and financial crises}

Between the years 2001 and 2017, the Ukrainian economy went through two major crises that influenced the financial behavior of Ukrainian households. In order to evaluate the quantitative characteristics of these assumptions, it is expedient to isolate the time ranges of the corresponding periods. Thus, let us characterize the periods between 2005 and 2007 and between 2010 and 2013 as stable, and the periods between 2008 and 2009 and between 2014 and 2016 as unstable or crisis periods. During the 2008-2009 crisis, the level of household savings varied in changing directions. At the crisis onset in 2008, household savings dropped by $39.90 \%$, while incomes grew by $35.67 \%$. At the same time, expenditures on non-financial assets increased by $196.96 \%$ - a change triggered by the desire of households to protect their savings from being devalued by buying real estate, of which value was increasing rapidly under the influence of a depreciating national currency.

Next year (in 2009). households' savings increased by $210 \%$, while incomes grew by $5.75 \%$ and expenditures on real estate fell by $64.45 \%$ in spite of an increase in the prices of financial assets. This confirms that asset prices do have an influence on the financial behavior of Ukrainian households.

During the 2014-2016 crises that resulted from the outbreak of an armed conflict on Ukrainian territory, the expenditures of households on financial assets declined continuously, becoming negative in 2016, with the expenditures on non-financial assets following a similar trend. Having said that, we also note that the income of Ukrainian households experienced a decrease of $2.06 \%$ in 2014, but increased in both 2015 and 2016. The fact is that the rapid increase in the inflation rate to $24.9 \%$ in 2014 and $43.3 \%$ in 2015 was the reason Ukrainian households were not only unable to increase savings, but also had to turn to the savings accumulated by them in the past to subsidize their current consumption needs. The negative net expenditures by households on purchasing non-financial assets during 2015 and 2016 indicate that during the period mentioned households sold more real estate and other similar assets than they purchased.

We want to find out if the economic downturns influenced the households' choice of financial and non-financial assets. The validity of the proposed hypothesis will be checked with the help of chi-square test (tab. 4). Hypothesis H2: there is no significant difference between the households' choice and the economic downturns.

Tab. 4 - Pilot parameters of chi-square test hypothesis H2. Source: own research

\begin{tabular}{|l|l|l|l|l|}
\hline \multirow{2}{*}{ Category } & \multicolumn{2}{|l|}{ Observed } & Expected \\
\cline { 2 - 5 } & before crises & crises & before crises & crises \\
\hline$\Delta \mathrm{S} / \Delta \mathrm{I}$ & 6 & 2 & 5 & 2.5 \\
\hline$\Delta \mathrm{W} / \Delta \mathrm{I}$ & 4 & 3 & 5 & 2.5 \\
\hline$\chi^{2}=0.439$ & \multicolumn{3}{|l}{} \\
\hline
\end{tabular}

The empirical value of $\chi^{2}$ test statistic is lower than the critical one. The closest value for $\mathrm{df}=1$ and 0.539 is between 0.500 and 0.250 . This low p-value (min. $25.00 \%$ ) means that the H2 hypothesis should be rejected. So, the households' choice of financial and non-financial assets is rather strongly affected by phases of the economic cycle. 
The characteristic feature of the financial behavior of Ukrainian households is that increases in their living standards initially lead them to increase their savings in the form of financial assets, and only subsequently induce them to start accumulating non-financial assets. Conversely, when living standards decrease, households initially reduce their savings, and only sell the real assets they accumulated as a last resort. These results allow us to assert that households accumulate financial assets primarily with the aim of creating a safety net to protect themselves against financial hardship during financial and economic downturns. Unlike the inhabitants of most other Eastern European countries, due to a host of reasons. Ukrainians rarely borrow to finance their expenses, with accumulated savings being a more reliable source of financing expenses during the periods of crisis and falling incomes. Hence, the motives of Ukrainian households to save are twofold: to postpone present consumption and to create a financial reserve intended to fulfill a psychological protection function.

\subsection{Financial crises and changes of household financial assets}

Using the decomposition method allowed us to evaluate the peculiarities of how Ukrainian households make decisions regarding which types of financial assets to purchase. International statistics classifies the financial assets held by households as follows: currency and deposits; securities other than shares; loans; shares and other equity; net equity of households in life insurance reserves; net equity of households in pension funds; prepayments of premiums and reserves against outstanding claims; and other accounts receivable. In Ukraine, the State Statistical Agency publishes data regarding only two types of financial assets held by households: 1) foreign currency (FC); 2) deposits and savings in the form of securities (DS).

For the entire period of the observation, foreign currency and bank deposits (BD) dominated the structure of financial assets held by Ukrainian households, comprising up to $90 \%$ of all financial assets held. However, between 2005 and 2015, the types and amounts of financial assets varied significantly. For example, in 2009 and 2011, foreign currency held a dominant position in the structure of financial assets held by households, whereas between 2005 and 2008, in 2010. 2012 and 2013, the same was true for bank deposits (see Fig. 2).

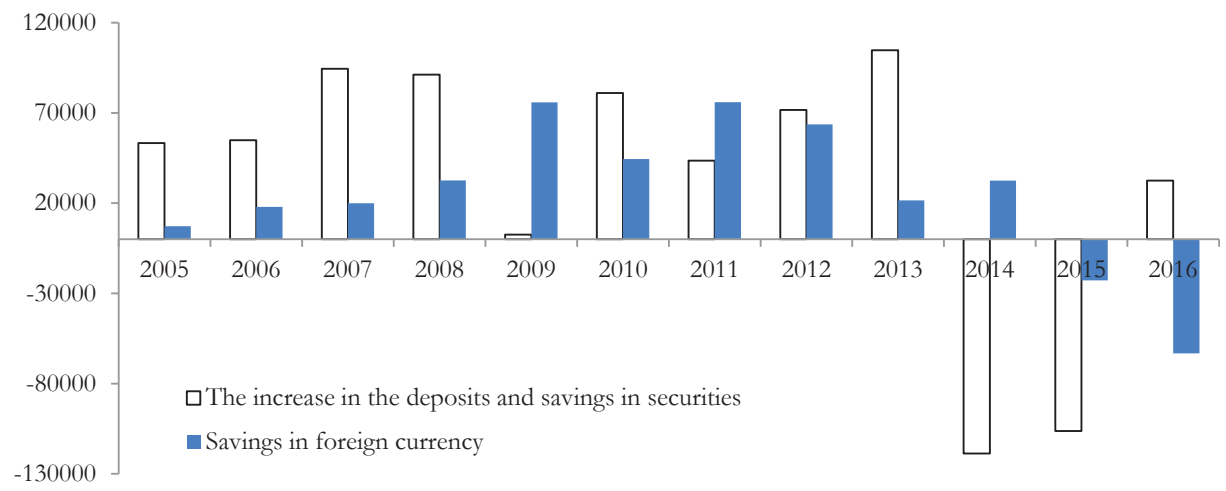

Fig. 2 - Dynamics of the amounts of the main types of financial assets held by Ukrainian households in 2005 2016. Source: own research 
It is worth mentioning that the residents of many countries share the preference of Ukrainians for using predominantly foreign currency and bank deposits as savings vehicles. For example, in the Slovak Republic, the share of foreign currency and bank deposits in the population's overall savings varied between $68.11 \%$ in 2004, and 62.26\% in 2015. In Poland, this indicator stood at $47.97 \%$ in 2015 .

In terms of the structure of their savings, the financial behavior of households in Ukraine is similar to the behavior of households of other Central and Eastern European countries. In 2015 , the inhabitants of the following countries held the largest shares of their financial assets in foreign currency and bank deposits: Greece (66.3\%; reaching as high as $79.6 \%$ in 2011); the Slovak Republic (62.3\%). the Czech Republic (50.4\%). Slovenia (50.0\%). and Luxemburg (49.8\%). In other regions. the share of foreign currency and bank deposits among the financial assets held by households was also quite high-in Japan (51.3\%) and Turkey (75.8\%). while being the lowest in Chile (13.0\%). the United States $(13.39 \%)$. Sweden (13.79\%). Iceland $(14.2 \%)$. Denmark (15.8\%). and the Netherlands (18.25\%). As is apparent from these numbers, populations in developing countries largely prefer to hold their savings in foreign currencies and deposits.

During the 2008-2009 crisis. Ukrainians rapidly bought up foreign currency, with the amount of financial assets held in 2009 increasing by $132.89 \%$, while the price of foreign currency increased by over $70 \%$. Also during this period, the amount of bank deposits decreased by $97.23 \%$ in spite of an increase in interest rates on bank deposits from 10\% APR in September 2008 to $20 \%$ APR in February 2009. This shows that the intrinsic value of financial assets is not the key factor driving the decisions of households to invest in certain assets. In other words. Ukrainians prefer to use foreign currency as a savings vehicle regardless of the existing exchange rates or expectations of future exchange rates. These uncovered relationships confirm the validity of the "law of instrument" proposed by Kaplan (1964) which posits that individuals are inclined to overestimate the utility of the financial instruments they are familiar with, hence preferring to hold savings in foreign currency during economic downturns despite low expected returns.

During the 2014-2016 crises, households actively withdrew bank deposits and sold their foreign currency savings, with the former, generally-speaking, being the preferred option to the latter. This confirms that Ukrainians trust foreign currency more than bank deposits as a savings vehicle. The high variability of the proportions of savings that Ukrainians hold in different types of financial assets over time speaks to the high elasticity of circumstances.

We sought to determine if the macroeconomic indicators influence the structure of financial assets. Two hypotheses were tested. Hypothesis H3: there is no significant difference between the household choice of financial asset type and the deposit interest rate. Hypothesis H4: there is no significant difference between the household choice of financial assets type and the increase in income. The validity of the proposed hypotheses were teste during a chi-square test (see Tab. 5). 
Tab. 5 - Test of hypotheses. Source: own research

\begin{tabular}{|l|l|l|}
\hline & Financial assets type \\
\hline & Chi-Square Value & P-Value \\
\hline H3: Relationship: financial assets and deposit interest rate & 0.2698 & $7.815^{* *}$ \\
\hline H4: Relationship: financial assets and increase in income & 0.4965 & $6.251^{*}$ \\
\hline
\end{tabular}

* indicates significance level at 0.10 level. $* *$ indicates significance level at 0.05 level

As the critical values are higher than the empirical values, both hypotheses $\mathrm{H} 3$ and $\mathrm{H} 4$ were rejected, i.e. there is a significant difference between household choice of financial assets type and deposit interest rate, and there is a significant difference between household choice of bank deposits and foreign currency and increase in income.

Based on the data presented in Tab. 6, we can make assumptions regarding the heterogeneity of the relationships discovered. It is apparent that the growth rate of the value of deposits held by households differed across periods, which means that changes occurred in terms of the financial stimuli dictating the behavior of the population before, during and in the aftermath of the crises.

Tab. 6 - Indicators of income elasticity of bank deposits. Source: own research

\begin{tabular}{|l|l|l|l|l|l|}
\hline & $2005-2016$ & $2005-2007$ & $2008-2009$ & $2010-2013$ & $2014-2016$ \\
\hline Times increase in income & 4.95 & 1.91 & 0.28 & 0.42 & 0.06 \\
\hline $\begin{array}{l}\text { Times increase in de- } \\
\text { posits }\end{array}$ & 4.25 & 1.22 & 0.23 & 0.22 & 0.32 \\
\hline $\begin{array}{l}\text { Income elasticity of bank } \\
\text { deposits }\end{array}$ & 0.86 & 0.64 & 0.82 & 0.52 & 5.33 \\
\hline
\end{tabular}

We can observe that the obtained values vary within a wide range. In the crisis periods, the income elasticity of deposits was higher than in the times of economic stability. In addition, it is impossible to determine a clear trend in the changes of income elasticity of bank deposits over time. During the stable period between 2005 and 2007, the value of the bank deposits held by households grew at a rate that was 36\% slower than the growth rate of their incomes, whereas between 2010 and 2013, the former grew 48\% slower than the latter. During the crisis period in 2008-2009, the growth rate of deposits lagged only $18 \%$ behind the growth rate of incomes. Finally, during the 2014-2016 crisis, the growth rate of deposits exceeded the growth rate of incomes 5.33 times. This growing more rapidly than during the pre-crisis period. This can be explained by the role of bank deposits as a financial safety net, which is in turn caused by the anxiety that households feel about their future income levels. Such irrational behavior of the part of the population can be explained using so-called "path dependency." a concept first introduced into behavioral finance theory in 2015 used to explain the dependence of individual financial decisions on the trajectory of past knowledge and experience, with the former representing a function of an individual's competencies that were acquired as a result of the latter (Dougal et al., 2015). In other words, history has a material impact on current decision-making and strategic planning, i.e. competencies that were acquired in the past define the financial decisions made by Ukrainian households today. 
In crisis II, the value of savings were negative at the positive values of this indicator during crisis I. Moreover, in crisis II, the rates of growth of deposits were higher than income growth, in contrast to the crisis I period, a finding which indicates the disorientation of households and expectations of significant inflation, i.e. crisis II was internal, and crisis I external. Therefore, we can determine that an internal crisis has a greater impact on the financial behavior of households than does an external crisis. Therefore, for a country's competitiveness, an internal crisis has more negative consequences.

\section{CONCLUSION}

During the past 20 years, the Ukrainian economy has gone through several crises which had a substantial negative impact on the financial prosperity of Ukrainian households, leaving their mark on the psychology of their financial behavior and fostering a strong urge to accumulate financial reserves in the form of savings. Such a feature is specific to households in Ukraine and is not a significant characteristic of households in other countries (Hronová \& Hindls, 2013; Utzig, 2016).

The 2014-2016 financial crises influenced the general characteristics of financial behavior of Ukrainian households: for the first time since Ukraine transitioned to a market economy, the savings level of Ukrainian households went negative, driven by high inflation rates and dropping real income levels. This dependence is typical for households in most European countries. Such behavior has a general positive impact on the level of competitiveness of the country's economy, as it determines the size of the domestic market.

Ukrainian households allocate an insignificant share of their overall income to purchasing nonfinancial assets, even though the country's per capita stocks of many such assets are low. In absolute terms, the amount of money directed towards purchasing financial assets exceeds the amount directed towards purchasing non-financial assets by several times. The decisions that Ukrainian households make regarding acquiring certain financial assets are influenced by their income levels, as well as the level of confidence they have in a given asset class. Bank deposits and foreign currency are the two most popular types of financial assets held by Ukrainian households. Increases in the value of foreign currency drive corresponding increases in household demand for foreign currency. Conversely, drops in the level of interest rates paid by banks on deposits do not cause proportional decreases in the amount of money Ukrainians store in bank deposits. Seeing as Ukrainian households generally only sell their foreign currency savings as a last resort, it can be inferred that they trust foreign currency more than bank deposits as a store of value. A large amount of financial assets accumulated by households has a positive impact on the country's competitiveness, as these assets form great internal resources for financing the economy.

Given that the general behavioral characteristics of households vary dramatically between economic downturns and periods of economic stability, it is crucial to take into account the particularities of their financial behavior when formulating policies regulating the financial system to maximize efficiency and thus bring more balance to Ukraine's financial market. 


\section{References}

1. Barber, B. M. \& Odean, T. (2001). Boys will be boys: Gender. overconfidence. and common stock investment. The Quarterly Journal of Economics. 116 (1), 261-292. https://doi. org $/ 10.1162 / 003355301556400$

2. Campbell, J. Y. (2006). Household Finance. The Journal of Finance, 61 (4). 1553-1604. https:// doi.10.1111/j.1540-6261.2006.00883.x.

3. Choi, J. J., Laibson, D., Madrian, B. C. \& Metrick, A. (2009). Reinforcement Learning and Savings Behavior. The Journal of Finance, 64 (6), 2515-2534. https://doi.org/10.1111/j.15406261.2009.01509.x

4. Côté, A. (2011). Household finances and economic growth. BIS central bankers'speeches. Kingston. Ontario. 10 January. 4.

5. Dougal, C., Engelberg, J., Parsons, C. A., \& Wesep, E. D. (2015). Anchoring on Credit Spreads. Journal of Finance, 70 (3), 1039-1080. https://doi.org/10.1111/jofi.12248.

6. Froud, J., Sukhdev, J., Montgomerie, J., \& Williams, K. (2010). Escaping the Tyranny of Earned Income? The Failure of Finance as Social Innovation. New Political Economy, 15 (1). 147-164. https://doi:10.1080/13563460903553723

7. Fuller, G. W. (2015). Household Finance in Contemporary Capitalism: Facts in Search of Theory. Preliminary conference draft prepared for EUSA 2015. http://aei.pitt. edu/79015/1/Fuller.pdf.

8. Hronová, S. \& Hindls, R. (2013). Czech Households in the Years of Crises. Statistics and Economic Journal, 93 (4), 4-23.

9. Illyashenko, P. (2017) Behavioral Finance: Historical Review and Main Foundations. Herald of the National bank of Ukraine. March. 30-57.

10. Kaplan, A. (1964). The Conduct of Inquiry: Methodology for Behavioural Science. San Francisco: Chandier Publishing Company.

11. Kolasa, A. \& Liberda, B. (2015). Determinants of Saving in Poland: Are They Different from Those in Other OECD Countries? Eastern European Economics, 53 (2), 124-148.

12. Ludvigson, S. (2013). Advances in Consumption-Based Asset Pricing. Handbook of the Economics of Finance, 2. 799-906.

13. Stango, V.. \& Zinman, J. (2007). Fuzzy Math and Household Finance: Theory and Evidence. Available at: http://www.dartmouth.edu/ jzinman/Papers/Stango\&Zinman_ FuzzyMath\&HHfin_sep07.pdf

14. Stango, V.. \& Zinman, J. (2009). Exponential Growth Bias and Household Finance. The Journal of Finance, 64 (6), 2807-2849. https://doi.org/10.1111/j.1540-6261.2009.01518.x

15. Stone, R. (1966). Mathematic in the Social Sciences and Other Essays. Cambridge. Mass. MIT Press; London. Chapman and Hall.

16. Thaler R.H. (1993). Advances in Behavioral Finance. NY: Russell Sage foundation.

17. World Economic Forum (2019). The Global Competitiveness Report 2018. Retrieved from: http:// www.weforum.org 
18. U.S. Government Accountability Office. (2010). Information security: Concerted effort needed to consolidate and secure Internet connections at federal agencies (Publication No. GAO-10-237). Retrieved from http://www.gao.gov/assets/310/301876.pdf

19. Utzig, M. (2016). Value and structure of households' financial assets in Poland. Paper presented at the 2016 International Conference "Economic science for rural development". $41,301-332$.

20. Vladová, A. (2005). International Comparison of the Propensity to Consume in the Household Sector. BIATEC. 13 (7), 12-15.

21. Yamana, K. (2016). Structural Household Finance. PRI Discussion Paper Series. No.16A07. Available at: http://www.mof.go.jp/pri/research/discussion_paper/ron279.pdf

22. Zhuk, M. (2015). Macroeconomic Determinants of Household Savings in Ukraine.

Economics and Sociology. 8 (3), 41-54. https://doi.org/10.14254/2071-789X.2015/8-3/3

\section{Contact information}

prof. Lyudmyla Shkvarchuk, ScD.

Lviv Polytechnic National University.

Institute of Economics and Management. Department of Finance

Lviv

Ukraine

E-mail:S_Lyuda16@ukr.net

ORCID: 0000-0001-7241-3961

prof. Rostyslav Slav'yuk, ScD.

Lviv Polytechnic National University.

Institute of Sustainable Development. Department of Entrepreneurship

Lviv

Ukraine

E-mail:Slavyuk@gmail.com

ORCID: 0000-0002-0904-8970 